\title{
AN EFFICIENT PROTOCOL TO PERFORM GENETIC TRACEABILITY OF TISSUE AND FOODS FROM Geoffroea decorticans
}

\section{UN PROTOCOLO EFICIENTE PARA REALIZAR LA TRAZABILIDAD GENÉTICA EN TEJIDOS Y ALIMENTOS DE Geoffroea decorticans}

\author{
Roberto Contreras $^{1 *}$, Vincenzo Porcile ${ }^{1}$, Drago Guggiana-Nilo ${ }^{2}$, and Fernanda Aguayo ${ }^{1}$ \\ ${ }^{1}$ Centro de Investigación para el Desarrollo Sustentable de Atacama (CRIDESAT), Universidad de \\ Atacama, Av. Copayapu 485, Copiapó, Chile. \\ ${ }^{2}$ Max Planck Institute of Neurobiology, Am Klopferspitz 18, 82152 Planegg, Germany. \\ *Corresponding author E-mail: roberto.contreras@uda.cl
}

\section{ABSTRACT}

The quality of a DNA isolation method depends, among others, on the target tissue and the metabolites therein. Geoffroea decorticans Burkart (chañar) is a species that has nutritional and pharmacological potential. However, an effective method of DNA extraction capable of facilitating population studies and food genetic traceability has not been studied yet. The objective of the present work was to evaluate four methods of DNA extraction from leaves and chañar-based foods. The methods were evaluated based on yield, DNA purity, and molecular markers. The CCI-P (CTAB/ Chloroform-Isoamylalcohol/pellet) method showed the highest yield of DNA obtained from leaves. However, the CPCI-SC (CTAB/Phenol-Chloroform-Isoamylalcohol/silica-column) method was the only one that resulted in acceptable DNA quality with both parameters (A260/A280 and A260/A230). The leaf DNA obtained with this method showed a greater amount of fragments with RAPD, and an acceptable amount of fragments with ISSR. On the other hand, the CCI-P method showed a higher yield of DNA from arrope de chañar (syrup). However, the CPCI-SC method was the only one that had relatively better DNA quality, which allowed the amplification of molecular markers. Regarding chañar flour, the CPCI-SC method showed the highest yield, DNA quality and good amplification with molecular markers. Therefore, the CPCI-SC extraction method is efficient for obtaining DNA from different matrices, and can support studies for a possible designation of origin of chañar-based foods.

Key words: DNA isolation, chañar, Geoffroea decorticans, quality control, ISSR, RAPD, SSR.

\section{RESUMEN}

La calidad de un método de aislamiento de ADN depende, entre otros, del tejido objetivo y sus metabolitos. Geoffroea decorticans Burkart (chañar) es una especie que tiene potencial nutricional y farmacológico. Sin embargo, no se ha estudiado un método eficaz de extracción de ADN, capaz de facilitar estudios de poblaciones y trazabilidad genética de alimentos. El objetivo del presente trabajo fue evaluar cuatro métodos de extracción de ADN de hojas y de alimentos a base de chañar. Los métodos se evaluaron en función del rendimiento, pureza del ADN y marcadores moleculares. El método CCI-P (CTAB/cloroformo-alcohol-isoamílico/pellet) mostró el mayor rendimiento de ADN obtenido de las hojas. Sin embargo, el método CPCI-SC (CTAB/fenol-cloroformo-alcohol isoamílico/columna de sílice) fue el único que resultó en una calidad de ADN aceptable con ambos

Received: 30 April 2019. Accepted: 13 June 2019. 
parámetros (A260/A280 y A260/A230). El ADN de hoja obtenido con este método mostró mayor cantidad de fragmentos con RAPD, y una cantidad aceptable de fragmentos con ISSR. Por otro lado, el método CCI-P mostró un mayor rendimiento de ADN de arrope de chañar (jarabe). Sin embargo, el método CPCI-SC fue el único que tuvo una calidad de ADN relativamente mejor, lo que permitió la amplificación de marcadores moleculares. Con respecto a la harina de chañar, el método CPCI-SC mostró mayor rendimiento, calidad de ADN y buena amplificación con marcadores moleculares. Por lo tanto, el método de extracción CPCI-SC es eficiente para obtener ADN de diferentes matrices, así como para apoyar estudios para una posible designación de origen de alimentos a base de chañar.

Palabras clave: Aislación de ADN, chañar, Geoffroea decorticans,control de calidad, ISSR, RAPD, SSR.

\section{INTRODUCTION}

Geoffroea decorticans Burkart is an arboreal species, commonly known as chañar. Geographically, it can be found in southern Peru, Argentina, northern Chile (Atacama Desert), Bolivia, the Paraguayan Chaco and western Uruguay (Charpentier, 1998; Costagama et al., 2016). Its fruits are a valuable source of nourishment, both for humans and animals, in its semi-desertic habitats (Charpentier, 1998). Moreover, leaves and flowers are used in traditional medicine (Jiménez-Aspee et al., 2017). Currently, there are several derivatives from its fruits with economic potential, such as chañar flour and a syrup termed "arrope", which can be targeted both for human and animal consumption (Orrabalis et al., 2013; Reynoso et al., 2016). Both the syrup and flour present sedative, antitussive, expectorant, anticatarrhal, balsamic, emollient, antiasthmatic, and antidiarrheal effects, and also activity against respiratory and urinary infections (Costagama et al., 2016; Hurrell and Ulibarri, 2011; Reynoso et al., 2016).

Raw materials are essential to produce food with high nutritional value. Therefore, species identification in food products is essential to prevent fraud. In this sense, DNA markers are the most effective instrument to monitor the genetic identity of food components in processed foods (Galimberti et al., 2013). Despite the apparent simplicity of DNA extraction in plants, there are many problems associated with its isolation (Aleksic et al., 2012; Ginwal and Maurya, 2010). In particular, both quality and integrity of the isolated DNA directly affect the results of downstread experiments (Ginwal and Maurya, 2010) since the excess of cell debris and proteins can alter, for example, the polymerase chain reaction (PCR) (Wilson, 1997; Lorenz, 2012; Schrader et al., 2012). DNA isolated by the CTAB (cetyl trimethylammonium bromide) method is used for many purposes such as cloning, PCR, DNA sequencing (Allen et al., 2006; Inglis et al., 2018), and genetic traceability of foodstuffs (Di
Bernardo et al., 2007; Turci et al., 2010; Pereira et al., 2016), among others. In general, this method is adapted according to the plant tissue or type of processed food. Thus, to obtain pure and highperformance DNA, the first step of cell lysis can be modified by adding components such as PVP40, Sorbitol, Sarcosyl, 2-Mercaptoethanol and $\mathrm{NaCl}$ (Allen et al., 2006). For the second step, which corresponds to the separation of protein and inhibitory components, phenol/chloroform can be used (instead of chloroform only) (Allen et al., 2006), or alternatively, silica columns (Ohmori et al., 2008). However, some components have disadvantages. For example, phenol is very toxic and needs be handled carefully (Allen et al., 2006), while silica columns do not bind all DNA to the membrane, resulting in lower yields of extraction (Kopecká et al., 2014). On the other hand, there are several commercial DNA isolation kits available that can be less time consuming and provide pure DNA extract, but they are expensive and consider only some plant species or processed foods. Parameters such as high purity and high quality, time consumption, yield and cost per sample should be considered when selecting an appropriate extraction method.

Among the possible molecular techniques are Random Amplified Polymorphic DNA (RAPD) (Williams et al., 1990; Contreras et al., 2018a) and Inter-Simple Sequence Repeats (ISSR) (Zietkiewicz et al., 1994; Contreras et al., 2018b), which are commonly used for genetic studies. SSR markers have also been employed in a variety of cross identifications, and proven to be very effective for the authentication of food components, both from animal and plant species (Scarano and Rao, 2014). Plastid genes also show high discrimination power in plant species, such as the $r b c L$ and matK regions (Scarano and Rao, 2014).

The present work has resulted from ambiguous results obtained by the authors from PCRs targeting RAPD and ISSR molecular markers using DNA from leaf and fruit of Geoffroea decorticans. Therefore, we believe that by 
combining different protocols and components, Geoffroea decorticans DNA can be effectively isolated from plant tissue and processed foods. The objective of the present work was to evaluate four methods of DNA extraction from leaf and foods of Geoffroea decorticans in terms of yield and quality of purification by amplifying molecular markers.

\section{MATERIALS AND METHODS}

\section{Plant material and processed food for} homogenization

Samples of Geoffroea decorticans were collected in northern Chile (Atacama Desert), from the Arica-Parinacota to the Atacama Region. Trees from six locations, Azapa, Chaca, Pachica, San Pedro, Copiapó and Totoral (Table 1), were selected. Young leaves from chañar trees were sampled. The leaves were homogenized with liquid nitrogen to solidify until a light powder was obtained. Then, $100 \mathrm{mg}$ of the powder were weighted into $2 \mathrm{~mL}$ microcentrifuge tubes; 3 replicates per sample were prepared.

There are two main foods from the chañar's fruit that are popular in northern Chile: the chañar arrope (sweet syrup) and chañar flour. Before isolating DNA from processed foods, information about the thermal manipulations performed on the prime substrate is required. Briefly, to prepare chañar arrope, the fruits are boiled in water for 10 min, then the solids are filtered with cotton fabric and the extract is transferred to a pot. Finally, 10 $\mathrm{L}$ of filtered extract are boiled for approximately $8 \mathrm{~h}$, with cooking time proportional to the volume of chañar extract. In the case of chañar flour, the mesocarp and epicarp of the fruit are ground strongly in a mortar until a very fine powder is obtained. Then, $100 \mathrm{mg}$ of the powder were weighted in $2 \mathrm{~mL}$ microcentrifuge tubes; 3 replicates per sample were prepared.

\section{DNA Isolation \\ CTAB/Chloroform-Isoamylalcohol/pellet (CCI-P)}

A CTAB method with modifications described by Contreras et al (2018c) was used. Briefly; a) Lysis: $7 \mu \mathrm{L}$ of beta-mercaptoethanol, $4 \mu \mathrm{L}$ of $10 \mathrm{mg} \mathrm{mL}^{-1}$ Proteinase $\mathrm{K}$ and $700 \mu \mathrm{l}$ of CTAB preheated to $65^{\circ} \mathrm{C}$ for $15 \mathrm{~min}\left(4 \% \mathrm{p} \mathrm{v}^{-1} \mathrm{PVP}-40\right.$, $100 \mathrm{mM}$ Tris- $\mathrm{HCl} \mathrm{pH} 8 ; 1,2 \mathrm{M} \mathrm{NaCl} ; 20 \mathrm{mM}$ EDTA, 2\% CTAB) were added to each tube; b) Incubation 1 . The samples were stirred in a vortex and then incubated in a water bath at $65^{\circ} \mathrm{C}$ for $60 \mathrm{~min}$, inverting the tubes every $15 \mathrm{~min}$. The tubes were then centrifuged at $14000 \mathrm{rpm}$ at $4^{\circ} \mathrm{C}$ for $10 \mathrm{~min}$, and the top aqueous phase was taken for further processing $(\sim 600 \mu \mathrm{L})$ in a new tube. $700 \mu \mathrm{L}$ of a chloroform/isoamyl alcohol (24:1) solution were added to each tube and mixed via inversion of the tubes at room temperature for 2 $\min$. These tubes were then centrifuged at 14000 $\mathrm{rpm}$ at $4^{\circ} \mathrm{C}$ for $10 \mathrm{~min}$, and the top phase was recovered for further processing $(\sim 500 \mu \mathrm{L})$, trying not to perturb the lower fraction of the tube; $c$ ) Incubation 2. This supernatant was transferred to a new tube. Next, $5 \mu \mathrm{L}$ of $10 \mathrm{mg} / \mathrm{mL}$ RNAse were added to every tube, followed by incubation at $37^{\circ} \mathrm{C}$ for $30 \mathrm{~min}$; d) Precipitate of DNA. Two thirds of isopropanol at $-20^{\circ} \mathrm{C}$ were added to the tubes (333 $\mu \mathrm{L}$ of isopropanol for $500 \mu \mathrm{L}$ of solution in this case), which were then inverted 30 times at

Table 1. Chañar samples used for the extraction methods, classified by location and georeferential coordinates.

Tabla 1. Muestras de chañar utilizadas para los métodos de extracción, separadas por ubicación y coordenadas georreferenciales.

\begin{tabular}{lllc}
\hline Sample & Location & Coordinates & Altitude $(\mathbf{m})$ \\
\hline Azapa & Azapa Valley & $18^{\circ} 29^{\prime} 34.7^{\prime \prime} \mathrm{S}$ & 248 \\
& & $70^{\circ} 16^{\prime} 43.2^{\prime \prime} \mathrm{W}$ & \\
Chaca & Chaca Valley & $18^{\circ} 48^{\prime} 10.8^{\prime \prime} \mathrm{S}$ & 278 \\
& & $70^{\circ} 10^{\prime} 12.9^{\prime \prime} \mathrm{W}$ & \\
Pachica & Tarapaca Valley & $1^{\circ} 51^{\prime} 50.8^{\prime \prime} \mathrm{S}$ & 1,649 \\
& & $69^{\circ} 24^{\prime} 35.7^{\prime \prime} \mathrm{W}$ & \\
S. Pedro & San Pedro de Atacama & $22^{\circ} 57^{\prime} 14.8^{\prime \prime} \mathrm{S}$ & 2,397 \\
& & $68^{\circ} 13^{\prime} 46.9^{\prime \prime} \mathrm{W}$ & \\
Copiapó & Copiapó Valley & $27^{\circ} 20^{\prime} 39.3^{\prime \prime} \mathrm{S}$ & 360 \\
& & $70^{\circ} 21^{\prime} 46.0^{\prime \prime} \mathrm{W}$ & \\
Totoral & Totoral Valley & $27^{\circ} 54^{\prime} 02.3^{\prime \prime} \mathrm{S}$ & 260 \\
& & $70^{\circ} 57^{\prime} 42.4^{\prime \prime} \mathrm{W}$ & \\
\hline
\end{tabular}


room temperature to promote mixing, before being transferred to ice for $40 \mathrm{~min}$. The tubes were centrifuged at $14000 \mathrm{rpm}$ for $10 \mathrm{~min}$ and all the supernatant was discarded; e) Wash. The remaining pellet was washed with $700 \mu \mathrm{L}$ of $70 \%$ ethanol and $10 \mathrm{mM} \mathrm{NH} \mathrm{NH}_{4} \mathrm{OAc}$ at $-20^{\circ} \mathrm{C}$, gently tapping the tube until the pellet dissociated from the bottom. After this incubation, the tubes were again centrifuged at $14000 \mathrm{rpm}$ for $2 \mathrm{~min}$ and the supernatant was discarded. This wash procedure was repeated 2 more times. After washing, the pellet was left to air dry at room temperature to remove all the remaining ethanol; d) DNA elution. Finally, the pellet was resuspended in $60 \mu \mathrm{L}$ of Tris-EDTA (TE), left at $4^{\circ} \mathrm{C}$ overnight, and finally stored at $-20^{\circ} \mathrm{C}$.

\section{CTAB/Chloroform-Isoamylalcohol/silica column (CCI-SC)}

This method follows the protocol described in CCI-P up to the addition of isopropanol at room temperature and mixing. a) DNA binding columns. The liquid was then transferred to a Hi-Bind mini columns (Omega Bio-tek) with a $2 \mathrm{~mL}$ collection tube attached. It was left incubating at room temperature for $2 \mathrm{~min}$, followed by centrifugation at $14000 \mathrm{rpm}$ for $2 \mathrm{~min}$. b) Wash. The precipitate was discarded and $700 \mu \mathrm{L}$ of $70 \%$ ethanol were

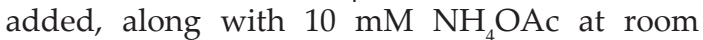
temperature. The mini columns were centrifuged at $14000 \mathrm{rpm}$ for $2 \mathrm{~min}$ and the precipitate was discarded. This wash procedure was repeated 2 more times. The empty mini columns were centrifuged at $14000 \mathrm{rpm}$ for $2 \mathrm{~min}$ to remove the remaining ethanol and the collection tube was replaced for a new $1.5 \mathrm{ml}$ tube. c) DNA elution. 60 $\mu \mathrm{L}$ of TE preheated to $65^{\circ} \mathrm{C}$ were added to each mini column, followed by incubation at $65^{\circ} \mathrm{C}$ for 5 $\mathrm{min}$. Finally, the tubes were centrifuged at 14000 rpm for $2 \mathrm{~min}$, the column was discarded and the $1.5 \mathrm{ml}$ tube with the extract was stored at $-20^{\circ} \mathrm{C}$.

\section{DNA extraction using a Commercial kit (CK)}

This method follows the protocol described for the commercial kit named Purelink ${ }^{\mathrm{TM}}$ Plant extraction kit (Invitrogen) as provided by the manufacturer ThermoFisher Scientific.

\section{CTAB/Phenol-Chloroform-Isoamylalcohol/ silica column (CPCI-SC)}

a) Lysis. $14 \mu \mathrm{L}$ of beta-mercaptoethanol, $14 \mu \mathrm{L}$ of $10 \mathrm{mg} / \mathrm{ml}$ Proteinase K, $14 \mu \mathrm{L}$ of $5 \%$ Sarkosyl, $0.045 \mathrm{~g}$ Sorbitol and $700 \mu \mathrm{L}$ of CTAB preheated to $65^{\circ} \mathrm{C}$ for $15 \mathrm{~min}$ were added to each tube. b) Incubation 1 . The samples were stirred in a vortex, and then incubated in a water bath at $65^{\circ} \mathrm{C}$ for $60 \mathrm{~min}$, inverting the tubes every $15 \mathrm{~min}$. The tubes were then centrifuged at $14000 \mathrm{rpm}$ at $4^{\circ} \mathrm{C}$ for $15 \mathrm{~min}$, and the top aqueous phase was taken for further processing $(\sim 700 \mu \mathrm{L})$ in a new tube. c) Incubation 2. $800 \mu \mathrm{L}$ of phenol/chloroform/ UltraPure $^{\mathrm{TM}}$ isoamyl alcohol (25:24:1) solution were added to each tube and mixed at $120 \mathrm{rpm}$ for $10 \mathrm{~min}$ in a shaker-incubator at $20^{\circ} \mathrm{C}$. d) Recovery. These tubes were then centrifuged at $14000 \mathrm{rpm}$ at $4^{\circ} \mathrm{C}$ for $15 \mathrm{~min}$ and the top phase was recovered for further processing $(\sim 550 \mu \mathrm{L})$, trying not to disturb the lower fraction of the tube. This supernatant was transferred to a new tube. Next, $8 \mu \mathrm{L}$ of $10 \mathrm{mg} \mathrm{mL}^{-1}$ RNAse were added to every tube, followed by incubation at $55^{\circ} \mathrm{C}$ for $8 \mathrm{~min}$. DNA binding, wash and DNA elution steps were performed as in the CCI-SC method.

\section{DNA isolation from chañar foods}

The four DNA isolation methods described above (CCI-P, CCI-SC, CK and CPCI-SC) were used for DNA extraction from food products. DNA extract from wheat flour, which was extracted using a commercial kit method (Invitrogen Purelink ${ }^{\mathrm{TM} P l a n t), ~ w a s ~ u s e d ~ a s ~}$ negative control.

\section{DNA quality quantification}

The quality and concentration of the extracted genomic DNA from chañar leaf, chañar arrope, chañar flour and wheat flour (negative control) were verified using a COLIBRI microvolume spectrophotometer (Titertek-Berthold, Pforzheim, Germany). The ratio of absorbance at A260/A280 was used to assess DNA purity, with a threshold of $\geq 1.7$ to define it as "pure" (Demeke and Jenkins, 2010). The A260/A230 ratio was used as a secondary measure of DNA purity, with an acceptance range between 2.0 and 2.2 (Aleksic et al., 2012).

\section{ISSR and RAPD Amplification}

ISSR Marker UBC880 was selected for its consistent results during PCR. The $24 \mu \mathrm{L}$ PCR reaction consisted of $12 \mu \mathrm{L}$ of Master Mix SapphireAMPFast PCR 2x (TAKARA Clontech), $5 \mu \mathrm{L}$ of ISSR primer $(5 \mu \mathrm{M}), 2.5 \mu \mathrm{L}$ of genomic DNA ( $1 \mathrm{ng} \mu \mathrm{L}^{-1}$ ) and $4.5 \mu \mathrm{L}$ of nuclease free water. The reactions took place on a Swift Max Pro (ESCO) thermocycler under the following conditions: an initial step of $5 \mathrm{~min}$ at $94^{\circ} \mathrm{C}, 45$ cycles of $30 \mathrm{sec}$ at $94^{\circ} \mathrm{C}, 45 \mathrm{sec}$ at $52^{\circ} \mathrm{C}$ and $2 \mathrm{~min}$ at $72^{\circ} \mathrm{C}$, with a final extension of $6 \mathrm{~min}$ at $72^{\circ} \mathrm{C}$. The amplification products were separated via $1.8 \%$ agarose gel electrophoresis in $0.5 \mathrm{X}$ TBE for 1 hour $50 \mathrm{~min}$ at $100 \mathrm{~V}$ and stained with $4.6 \mu \mathrm{L}$ of Ethidium Bromide (EtBr) $\left(100 \mathrm{mg} \mathrm{mL}^{-1}\right)$. The gel was visualized on a UV transilluminator (Vilber Lourmat, Berlin, Germany) and photographed with a digital camera (Canon SX160 IS) for 
subsequent analysis. RAPD marker OPB-04 was selected for its consistent results during PCR. The $24 \mu \mathrm{L}$ PCR reaction consisted of: $12 \mu \mathrm{L}$ of Master Mix SapphireAMP Fast PCR 2X, $5 \mu \mathrm{L}$ of RAPD primer $(5 \mu \mathrm{M}), 1 \mu \mathrm{L}$ of genomic DNA $\left(5 n g \mu \mathrm{L}^{-1}\right)$ and $6 \mu \mathrm{L}$ of nuclease free water. The reactions took place on a Swift Max Pro Thermocycler under the following conditions: an initial step of $1 \mathrm{~min}$ at $91^{\circ} \mathrm{C}, 35 \mathrm{cycles}$ of $60 \mathrm{sec}$ at $91^{\circ} \mathrm{C}, 60 \mathrm{sec}$ at $36^{\circ} \mathrm{C}$ and $1.5 \mathrm{~min}$ at $72^{\circ} \mathrm{C}$, followed by a final extension step of $2 \mathrm{~min}$ at $72^{\circ} \mathrm{C}$. The PCR products were separated and visualized as described for the ISSR amplification.

\section{Protein content quantification}

For each DNA extraction method (in duplicate), two DNA samples with low PCR reproducibility were evaluated with regard to their protein content. This was quantified with a Qubit ${ }^{\mathrm{TM}} 3.0$ fluorometer using the Qubit Protein Assay Kit according to the manufacturer's instructions.

\section{PCR amplification from chañar foods}

The primer pairs used to amplify DNA from arrope and chañar flour, GdF1 5' ATGAGCCTTGGTATGGAA 3' / GdR1 5' CTTTGCTTTCGGAAAAC $3^{\prime}$ and GdF1 / GdR2 5' GGATTGCCCATTGTTA 3', were designed to amplify $107 \mathrm{bp}$ and $77 \mathrm{bp}$ segments, respectively, according to GenBank accession number AF208962.1 of the G. decorticans trnL gene (GdtrnL gene). On the other hand, primer pairs GdF2 5' CCCGACAATTAAGTTC 3' / GdR3 5' TGAATTGATCGCAGATTA 3' and GdF3 5' TCAAAGAATGCGCCTCT $3^{\prime \prime} /$ GdR4 5' GATCGTTCCGGGTTGAGA 3', were designed to amplify $70 \mathrm{bp}$ and $96 \mathrm{bp}$ bands, respectively, according to GenBank accession number AF270880.1 of the G. decorticans matK gene (GdmatK gene). These primer pairs were designed using Oligo ${ }^{\circledR}$ software. In addition, the primer pair targeting microsatellite Gsp. F119 (Naciri-Graven et al., 2005) was also used to analyze DNA from arrope and chañar flour. All polymerase chain reactions (PCR) were carried out in a total volume of $20 \mu \mathrm{L}$ containing 10 $\mu \mathrm{L}$ of DreamTaq PCR Master Mix 2X (Thermo Scientific), $1 \mu \mathrm{L}$ of forward primer $(5 \mu \mathrm{M}), 1 \mu \mathrm{L}$ of reverse primer $(5 \mu \mathrm{M})$ and $8 \mu \mathrm{L}$ of total genomic DNA $\left(1 \mathrm{ng} \mu \mathrm{L}^{-1}\right)$. The PCR amplification with the GdF1-GdR1, GdF1-gdR2, GdF2-GdF3 and GdF3-GdF4 primer pairs were performed in a Swift MaxPro thermocycler under the following conditions: an initial denaturation at $94^{\circ} \mathrm{C}$ for $4 \mathrm{~min}$, followed by 35 cycles of $45 \mathrm{~s}$ at $94^{\circ} \mathrm{C}, 45$ $\mathrm{s}$ at $50^{\circ} \mathrm{C}$ (annealing temperature), and $45 \mathrm{~s}$ at $72^{\circ} \mathrm{C}$, with a final extension at $72^{\circ} \mathrm{C}$ for $6 \mathrm{~min}$. The PCR amplification with the primer pair for microsatellite Gsp.F119 was performed in the same thermocycler used before, under the following conditions: an initial denaturation at $94^{\circ} \mathrm{C}$ for $4 \mathrm{~min}$, followed by 45 cycles of $35 \mathrm{~s}$ at $94^{\circ} \mathrm{C}, 35 \mathrm{~s}$ at $54^{\circ} \mathrm{C}$ (annealing temperature), and 35 $\mathrm{s}$ at $72^{\circ} \mathrm{C}$, with a final extension at $72^{\circ} \mathrm{C}$ for $4 \mathrm{~min}$. For the PCR assay from chañar flour, the DNA from wheat flour was used as negative control. Additionally, chañar leaf was used as positive control in all PCR food assays. The PCR products were separated and visualized as described for the ISSR amplification.

\section{Statistical analysis}

Statistical analysis was performed using XLstat 2012 (Fahmy and Aubry, 2003). Differences between DNA extraction methods in DNA concentration, DNA quality to $260 / 280$ absorbance ratios and 260/230 absorbance ratios were determined using ANOVA followed by Tukey's post-hoc pairwise comparisons. Results were considered statistically significant for $p$ values $\leq 0.05$. For the RAPD and ISSR primers, three independent PCR reactions for each sample were performed to note reproducibility of bands amplified and total number of bands. In addition, only consistent bands were considered.

\section{RESULTS}

\section{DNA extraction and PCR amplification from chañar leaf}

Significant differences in average DNA concentration obtained with the four DNA extraction methods from chañar leaf were observed (Table 2). The concentration of DNA obtained with the CCI-P method averaged 797.6 ng $\mu \mathrm{L}^{-1} \pm 252.4$, and was significantly higher $(\mathrm{P}<0.05)$ than the average values of the other methods, namely CCI-SC (376.6 $\mathrm{ng} \mu \mathrm{L}^{-1} \pm 173.9$ ), CK (17.7 ng $\left.\mu \mathrm{L}^{-1} \pm 4.09\right)$ method and CPCI-SC (227.6 ng $\mu \mathrm{L}^{-1} \pm 221.4$ ) (Table 2). However, the CPCI-SC method had significantly $(\mathrm{P}<0.05)$ better average values in terms of A260/A280 and A260/A230 ratios (2.01 and 2.66, respectively), compared to the average values of the other methods (Table 2). The A260/A280 values of the CCI-P, CCI-SC and CK methods were 1.87, 1.92 and 1.69, respectively, whereas the A260/A230 values of the CCI-P, CCI-SC and CK methods were $1.21,1.52$ and 0.79 , respectively (Table 2 ).

The DNA extracted using the four methods tested allowed for amplification of ISSR and RAPD patterns with the two targets analyzed (Fig. 1). The resulting ISSR and RAPD amplification profiles showed different number of bands for the same sample across methods (Fig. 1). Regarding DNA extraction with the CCI-P method, no clear 
Table 2. Comparison of processing time, concentration, $260 / 280$ ratio and $260 / 230$ ratio between the DNA samples extracted from $G$. decorticans leaves with each method.

Tabla 2. Comparación de tiempo de procesamiento, concentración, relación 260/280 y relación 260/230 entre las muestras de ADN extraídas de hojas de G. decorticans con cada método.

\begin{tabular}{|c|c|c|c|c|c|c|}
\hline $\begin{array}{l}\text { DNA } \\
\text { extraction } \\
\text { method }\end{array}$ & Sample & $\begin{array}{l}\text { Time } \\
\text { (h) }\end{array}$ & $\begin{array}{c}\text { Starting } \\
\text { material (g) }\end{array}$ & $\begin{array}{c}\text { DNA } \\
\text { concentration } \\
\left(\mathrm{ng} \mu \mathrm{L}^{-1}\right)\end{array}$ & $\begin{array}{c}260 / 280 \\
\text { Ratio }\end{array}$ & $\begin{array}{c}260 / 230 \\
\text { ratio }\end{array}$ \\
\hline \multirow[t]{6}{*}{$\overline{\text { CCI-P }}$} & Azapa & & $0.11( \pm 0.010)$ & $668.3( \pm 135.9)$ & $1.882( \pm 0.038)$ & $1.254( \pm 0.061)$ \\
\hline & Chaca & & $0.11( \pm 0.015)$ & $563.6( \pm 257.6)$ & $1.844( \pm 0.069)$ & $1.122( \pm 0.115)$ \\
\hline & Pachica & & $0.11( \pm 0.012)$ & $627.6( \pm 120.9)$ & $1.930( \pm 0.035)$ & $1.277( \pm 0.067)$ \\
\hline & S. Pedro & & $0.10( \pm 0.000)$ & $481.2( \pm 77.71)$ & $1.786( \pm 0.094)$ & $0.955( \pm 0.108)$ \\
\hline & Copiapó & & $0.12( \pm 0.006)$ & $1824( \pm 787.8)$ & $1.933( \pm 0.014)$ & $1.535( \pm 0.123)$ \\
\hline & Totoral & & $0.11( \pm 0.010)$ & $580.2( \pm 134.5)$ & $1.873( \pm 0.061)$ & $1.084( \pm 0.128)$ \\
\hline Average & & $24 \mathrm{~h}$ & & $797.6( \pm 252.4) \mathrm{a}$ & $1.87( \pm 0.052) b$ & $1.218( \pm 0.200) \mathrm{c}$ \\
\hline \multirow[t]{6}{*}{ CCI-SC } & Azapa & & $0.11( \pm 0.000)$ & $500.8( \pm 180.8)$ & $1.925( \pm 0.113)$ & $1.424( \pm 0.272)$ \\
\hline & Chaca & & $0.12( \pm 0.012)$ & $223.2( \pm 84.95)$ & $1.853( \pm 0.052)$ & $1.398( \pm 0.148)$ \\
\hline & Pachica & & $0.11( \pm 0.006)$ & $166.8( \pm 48.11)$ & $1.886( \pm 0.010)$ & $1.460( \pm 0.174)$ \\
\hline & S. Pedro & & $0.11( \pm 0.010)$ & $600.3( \pm 478.9)$ & $1.965( \pm 0.042)$ & $1.494( \pm 0.290)$ \\
\hline & Copiapó & & $0.11( \pm 0.006)$ & $549.1( \pm 239.3)$ & $1.936( \pm 0.090)$ & $1.505( \pm 0.395)$ \\
\hline & Totoral & & $0.11( \pm 0.006)$ & $219.4( \pm 11.38)$ & $2.002( \pm 0.001)$ & $1.860( \pm 0.116)$ \\
\hline Average & & $4 \mathrm{~h}$ & & $376.6( \pm 173.9) \mathrm{b}$ & $1.92( \pm 0.051) a b$ & $1.523( \pm 0.232) b$ \\
\hline \multirow[t]{6}{*}{$\mathrm{CK}$} & Azapa $\left(^{*}\right)$ & & $0.10( \pm 0.006)$ & $480.9( \pm 134.2)$ & $1.348( \pm 0.025)$ & $0.550( \pm 0.027)$ \\
\hline & Chaca & & $0.12( \pm 0.006)$ & $15.4( \pm 1.841)$ & $1.825( \pm 0.169)$ & $1.162( \pm 0.092)$ \\
\hline & Pachica & & $0.11( \pm 0.012)$ & $37.2( \pm 11.83)$ & $1.275( \pm 0.204)$ & $0.423( \pm 0.198)$ \\
\hline & S. Pedro & & $0.11( \pm 0.006)$ & $3.8( \pm 0.689)$ & $1.675( \pm 0.051)$ & $0.811( \pm 0.199)$ \\
\hline & Copiapó & & $0.10( \pm 0.006)$ & $23.0( \pm 1.982)$ & $1.777( \pm 0.030)$ & $1.399( \pm 0.195)$ \\
\hline & Totoral & & $0.11( \pm 0.006)$ & $4.3( \pm 1.489)$ & $1.921( \pm 0.137)$ & $0.186( \pm 0.180)$ \\
\hline Average & & $2 \mathrm{~h}$ & & $17.7( \pm 4.090) \mathrm{c}$ & $1.69( \pm 0.114) \mathrm{c}$ & $0.795( \pm 0.171) \mathrm{d}$ \\
\hline \multirow[t]{6}{*}{ CPCI-SC } & Azapa & & $0.10( \pm 0.006)$ & $51.10( \pm 5.105)$ & $1.880( \pm 0.080)$ & $3.143( \pm 0.702)$ \\
\hline & Chaca & & $0.12( \pm 0.010)$ & $62.20( \pm 13.50)$ & $1.915( \pm 0.055)$ & $2.829( \pm 0.109)$ \\
\hline & Pachica & & $0.11( \pm 0.012)$ & $177.7( \pm 83.80)$ & $2.006( \pm 0.033)$ & $2.434( \pm 0.392)$ \\
\hline & S. Pedro & & $0.11( \pm 0.006)$ & $302.7( \pm 24.26)$ & $2.147( \pm 0.020)$ & $2.462( \pm 0.197)$ \\
\hline & Copiapó & & $0.11( \pm 0.006)$ & $639.2( \pm 111.0)$ & $2.113( \pm 0.013)$ & $2.187( \pm 0.035)$ \\
\hline & Totoral & & $0.11( \pm 0.006)$ & $132.6( \pm 45.56)$ & $2.023( \pm 0.034)$ & $2.923( \pm 0.523)$ \\
\hline Average & & $5 \mathrm{~h}$ & & $227.6( \pm 221.4) b c$ & $2.01 \quad( \pm 0.039) \mathrm{a}$ & $2.663( \pm 0.326) \mathrm{a}$ \\
\hline
\end{tabular}

$\left({ }^{*}\right)$ Samples with out of range DNA concentration values were not considered in the ANOVA analysis.

and reproducible bands were observed in the six DNA samples of chañar using the ISSR marker (Fig. 1a). However, all the samples showed better pattern reproducibility with the RAPD marker (Fig. 1b). On the other hand, ISSR-PCR and RAPD-PCR were not reproducible for all the samples with the DNA extracted using the CCI-SC and CK methods (Fig. 1c, 1d, 1e and 1f). Conversely, the DNA samples extracted with the CPCI-SC method showed clear and reproducible bands for both ISSR-PCR and RAPD-PCR (Fig. $1 \mathrm{~g}$ and $1 \mathrm{~h})$. With the CCI-SC and CK methods, only four chañar DNA samples (Chaca, Pachica, San Pedro and Copiapó) were reproducible, but not the Azapa and Totoral samples. Due to the reduced reproducibility of the PCRs using the latter DNA samples, the amount of protein (PCR inhibitor) was measured. These two DNA samples showed values between 1.8 and $10.5 \mu \mathrm{g}$ $\mathrm{mL}^{-1}$ of protein using the CCI-P, CCI-SC and CK methods, while the CFCI-SC method resulted in a smaller amount (see Table 3). In particular, the CFCI-SC method yielded no numerical value due to the low detection limit of the instrument (below $1 \mu \mathrm{g} \mathrm{mL} \mathrm{m}^{-1}$ ) (Table 3). In terms of the total number of bands, more fragments were observed with the ISSR-PCR using DNA obtained with the CCI-SC method, followed by the CPCI-SC and $\mathrm{CK}$ methods. CCI-P resulted in fewer fragments (Table 4); whereas more fragments were observed 


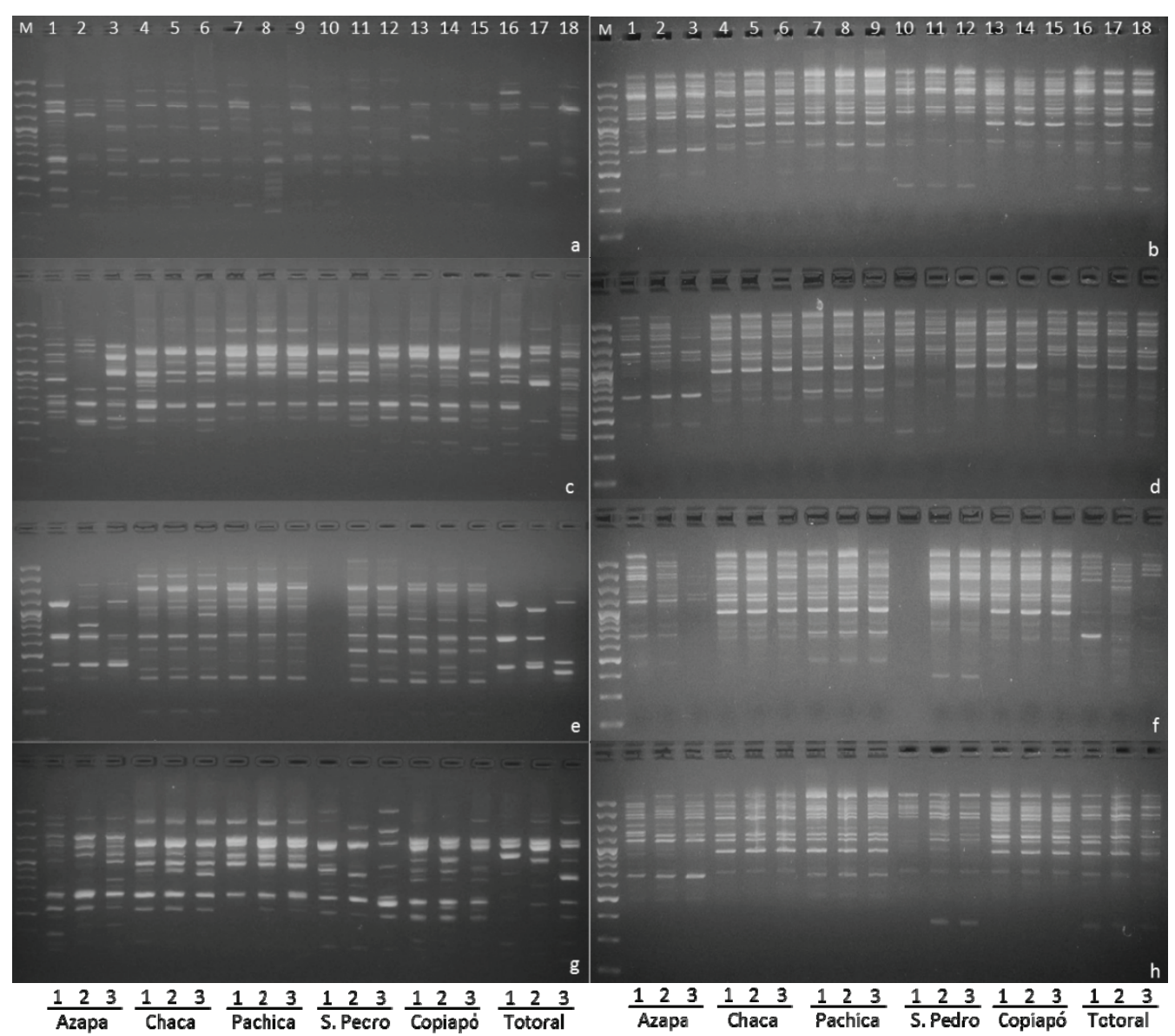

Fig. 1. PCR amplification profile obtained with ISSR and RAPD molecular markers and DNA from chañar leaves using four DNA extraction methods. PCR profile from chañar leaves using primer ISSR UBC880 (left) and RAPD primer OPB-04 (right). Letters a-b correspond to CCI-P; c-d to CCI-SC; e-f to CK; g-h to CPCI-SC.

Fig. 1. Perfil de amplificación de PCR obtenido con marcadores moleculares ISSR y RAPD y ADN de hojas de chañar usando cuatro métodos de extracción de ADN. Perfil PCR de hojas de chañar usando el cebador ISSR UBC880 (a la izquierda) y el cebador RAPD OPB-04 (a la derecha). Las letras a-b corresponden a CCI-P; c-d a CCI-SC; e-f a CK; g-h a CPCI-SC.

with RAPD-PCR using DNA obtained by the CPCI-SC method compared to the others methods (Table 4).

\section{DNA extraction and PCR amplification from} chañar foods

The concentration of DNA obtained from arrope with the CCI-P method averaged $61.53 \mathrm{ng}$ $\mu \mathrm{L}^{-1}$, and was significantly higher $(\mathrm{P}<0.05)$ than the average values obtained with the CCI-SC (5.59 ng $\left.\mu \mathrm{L}^{-1}\right), \mathrm{CK}\left(3.22 \mathrm{ng} \mu \mathrm{L}^{-1}\right)$ and CPCI-SC (19.3 ng $\mu \mathrm{L}^{-1}$ ) methods (Table 5). On the other hand, the concentration of DNA obtained from flour with the CPCI-SC method averaged $120.36 \mathrm{ng} \mu \mathrm{L}^{-1}$, and was significantly higher $(\mathrm{P}<0.05)$ than the values obtained with other methods (CCI-P: $67.68 \mathrm{ng} \mu \mathrm{L}^{-1}$, CCI-SC: $28.82 \mathrm{ng} \mu \mathrm{L}^{-1}$, and CK: 5.42 ng $\mu \mathrm{L}^{-1}$ ) (Table 5). The average A260/A280 ratio from arrope (1.63) and flour (1.79) with the CPCISC method was significantly higher $(\mathrm{P}<0.05)$ than the average values obtained with the other methods (CCI-P, CCI-SC and CK). The A260/ A230 ratios obtained for flour with CPCI-SC and CCI-SC methods (1.28 and 1.10 respectively) were significantly higher than with the CCI-P and CK methods; whereas the average A260/A230 ratio for arrope (1.08) using the CPCI-SC method was significantly higher than values observed with the others methods (Table 5).

Fig. 2 shows the PCR products obtained for 


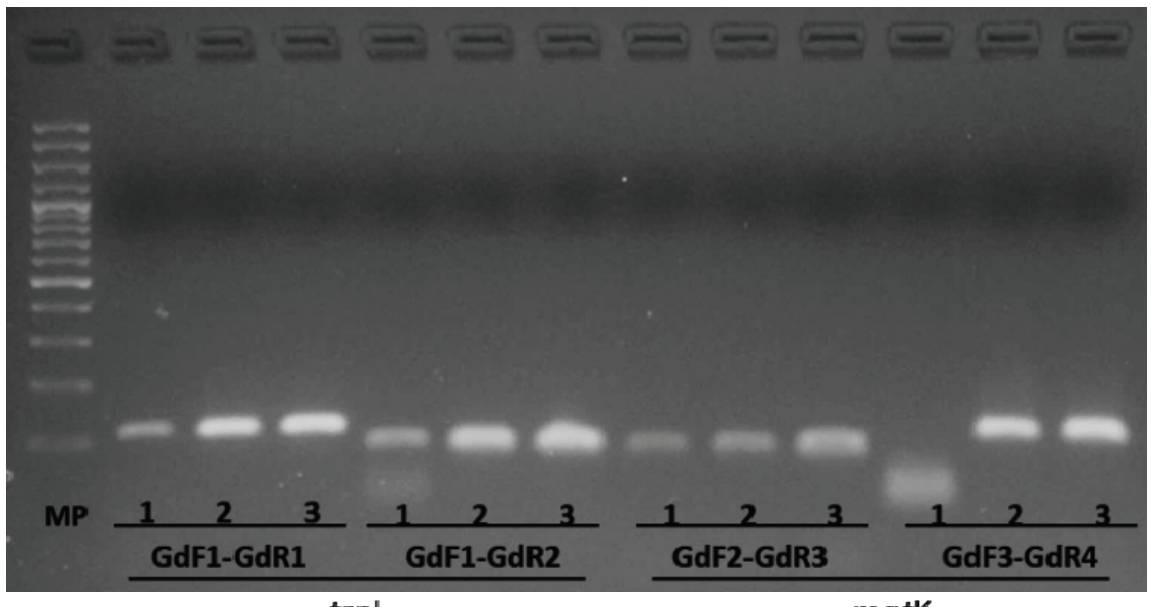

$\operatorname{trn\mathrm {L}}$

matk

Fig. 2. Electrophoresis of PCR amplified fragments obtained from chañar arrope DNA with primer pairs from genes GdtrnL and GdmatK. PCR amplification from arrope (1), leaf control 1 (2) and leaf control 2 (3), using primer pairs GdF1-GdR1 (107 bp) and GdF1-GdR2 (77 bp) from gene GdtrnL, and primer pairs GdF2-GdR3 (70 bp) and GdF3-GdR4 (96 bp) from gene GdmatK. MP: contains a molecular weight marker from $100 \mathrm{bp}$ to $3000 \mathrm{bp}$.

Fig. 2. Electroforesis de fragmentos amplificados por PCR obtenidos de ADN de arrope chañar con pares de cebadores de los genes GdtrnL y GdmatK. Amplificación de PCR de arrope (1), control de hoja 1 (2) y control de hoja 2 (3), usando pares de cebador GdF1-GdR1 (107 pb) y GdF1GdR2 (77 pb) del gen GdtrnL, y los pares de cebadores GdF2-GdR3 (70 pb) y GdF3-GdR4 (96 pb) del gen GdmatK. MP: contiene un marcador de peso molecular de $100 \mathrm{pb}$ a $3000 \mathrm{pb}$.

arrope and the control DNA, with the primers GdF1-GdR1 and GdF1-GdR2 targeting gene GdtrnL and the primers GdF2-GdR3 and GdF3GdR4 targeting gene GdmatK. All primer pairs amplified PCR products of the expected sizes using Arrope DNA, except the GdF3-GdR4 primer pair. Fig. 3 shows a successful SSR-PCR amplification (Gsp.F119) using DNA extracts from three chañar flour samples from Copiapó, two chañar flour samples from San Pedro and three positive controls from chañar leaves. However, no amplification was observed from the wheat flour (negative control). Likewise, PCR amplification from arrope DNA targeting the microsatellite Gsp.F119 was not observed (data not shown). In general, PCR assays with DNA extracts from arrope and flour showed successful amplification with DNA from the CPCI-SC method. However, they did not amplify with the DNA extracts from the other methods, with the exception of the flour DNA obtained with the CCI-SC method, which had shown successful PCR amplification.

\section{DISCUSSION}

Currently, there are multiple efficient protocols for the extraction and purification of DNA from plants (Saikar et al., 2013; Souza et al., 2012).
Despite this fact, DNA isolation from plants is usually affected by excessive contamination from secondary metabolites. Therefore, given the presence of these metabolites, every method needs to be adjusted to each plant species and even to each plant tissue (Wilson, 1997; Schrader et al., 2012). Additionally, DNA extraction from food matrices might be complicated, because they contain PCR inhibitors, such as calcium, chelators, phenolics, humic acids, etc. Moreover, food products are generally highly processed, therefore yielding low amounts of residual DNA (Di Bernardo et al., 2007; Yaila et al., 2018). The chañar fruit constitutes an important source of carbohydrates, flavonoids and polyphenols (Jiménez-Aspee et al., 2017; Maestri et al., 2001). However, these compounds prevent DNA isolation (Wilson, 1997; Schrader et al., 2012). Because of this, four DNA extraction methods were evaluated in this study. The quality of each extracted DNA sample was verified by spectrophotometry. An A260/A280 ratio of 1.8 indicates that the extracted DNA has high purity, while low values indicate the presence of proteins, phenol, or other contaminants that absorb strongly at or near $280 \mathrm{~nm}$ (Lucena-Aguilar et al., 2016). In addition, A260/A230 ratios $<1.8$ indicate the presence of contaminants such as peptides and polysaccharides (Di Bernardo et al., 2007; Liu 


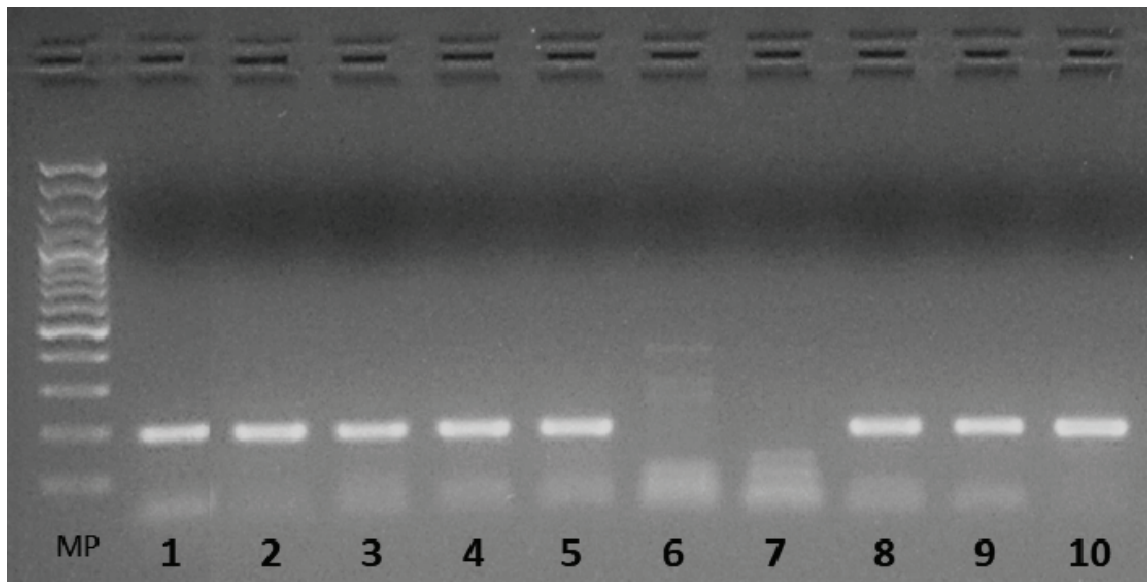

Fig. 3. PCR fragments obtained from chañar flour DNA with microsatellite Gsp.F119. PCR reactions from Copiapó chañar flour (1, 2 and 3), San Pedro chañar flour (4 and 5), wheat flour (6 and 7) and chañar leaves (positive control: 8, 9 and 10), using a primer pair targeting microsatellite Gsp.F119. MP: contains a molecular weight marker from $100 \mathrm{bp}$ to $3000 \mathrm{bp}$.

Fig. 3. Fragmentos de PCR obtenidos de ADN de harina de chañar con microsatélite Gsp.F119. Reacciones de PCR de la harina de chañar de Copiapó (1, 2 y 3), la harina de chañar de San Pedro ( 4 y 5), la harina de trigo (6 y 7) y hojas de chañar (control positivo: 8,9 y 10), utilizando la pareja de cebadores dirigido al microsatélite Gsp.F119. MP: contiene un marcador de peso molecular de $100 \mathrm{pb}$ a $3000 \mathrm{pb}$.

Table 3. Protein concentration of two samples from each DNA extraction method.

Tabla 3. Concentración proteica de dos muestras de cada método de extracción de ADN.

\begin{tabular}{lrrrr}
\hline Samples & \multicolumn{5}{c}{ Protein concentration $\left(\mu \mathrm{g} \mathrm{mL}^{-1}\right)$} \\
\cline { 2 - 5 } & \multicolumn{1}{c}{ CCI-P } & CCI-SC & CK & CPCI-SC \\
\hline Azapa & $1.8( \pm 0.53)$ & $2.92( \pm 0.13)$ & $10.5( \pm 0.35)$ & $<1$ (detection out of range) \\
Totoral & $5.35( \pm 0.86)$ & $2.26( \pm 0.24)$ & $<1$ (detection range out) & $<1$ (detection out of range) \\
\hline
\end{tabular}

Table 4. Result of fragments obtained with each DNA extraction method.

Tabla 4. Resultado de los fragmentos obtenidos con cada método de extracción de ADN.

\begin{tabular}{lcc}
\hline \multirow{2}{*}{ Method } & \multicolumn{2}{c}{ Total fragments } \\
\cline { 2 - 3 } & ISSR & RAPD \\
\hline CCI-P & 10 & 14 \\
CCI-SC & 15 & 12 \\
CK & 14 & 9 \\
CPCI-SC & 14 & 16 \\
\hline
\end{tabular}

et al., 2009). For leaf DNA extraction, the CPCISC method showed greater A260/A230 values than the other methods (CCI-P, CCI-SC and CK); however, this method showed only a moderate DNA yield. Although the CCI-P, CCI-SC and CK methods showed values within the accepted purity range ( $>1.8$ A260/A280 ratio), these methods had low A260/A230 values. The A260 / A280 value is generally considered for DNA extraction tests., but the second parameter (A260 / A230) is rarely used. As salt absorbs at $230 \mathrm{~nm}$, the reading from DNA extracts can be affected by contamination of salt impurities from the lysis solution (Lucena-Aguilar et al., 2016). Probably, a 
Table 5. Average values of concentration, 260/280 ratio and 260/230 ratio for DNA food samples extracted with four different methods.

Tabla 5. Valores promedio de concentración, relación 260/280 y relación 260/230 para las muestras de ADN de alimentos extraídas con cuatro métodos diferentes.

\begin{tabular}{llccccc}
\hline $\begin{array}{l}\text { DNA } \\
\text { extraction } \\
\text { method }\end{array}$ & $\begin{array}{l}\text { Chañar } \\
\text { food }\end{array}$ & $\begin{array}{c}\text { Time } \\
\mathbf{( H )}\end{array}$ & $\begin{array}{c}\text { Starting } \\
\text { material }\end{array}$ & $\begin{array}{c}\text { DNA } \\
\text { concentration } \\
\left(\mathbf{n g} \boldsymbol{\mu L}^{-1}\right)\end{array}$ & $\begin{array}{c}\mathbf{2 6 0 / 2 8 0} \\
\text { ratio }\end{array}$ & $\begin{array}{c}\mathbf{2 6 0 / 2 3 0} \\
\text { ratio }\end{array}$ \\
\hline CCI-P & Flour & 24 & $0.10 \mathrm{~g}$ & $67.688( \pm 34.6) \mathrm{b}$ & $1.375( \pm 0.205) \mathrm{b}$ & $0.375( \pm 0.049) \mathrm{b}$ \\
& Arrope & 24 & $250 \mu \mathrm{L}$ & $61.53( \pm 48.32) \mathrm{a}$ & $0.817( \pm 0.016) \mathrm{b}$ & $0.175( \pm 0,049) \mathrm{b}$ \\
$\mathrm{CCI}-\mathrm{SC}$ & Flour & 4 & $0.10 \mathrm{~g}$ & $28.82( \pm 14.67) \mathrm{c}$ & $1.28( \pm 0.311) \mathrm{b}$ & $1.1( \pm 0.424) \mathrm{a}$ \\
& Arrope & 6 & $250 \mu \mathrm{L}$ & $5.59( \pm 4.73) \mathrm{b}$ & $0.825( \pm 0.007) \mathrm{b}$ & $0.305( \pm 0.205) \mathrm{b}$ \\
$\mathrm{CK}$ & Flour & 2 & $0.10 \mathrm{~g}$ & $5.42( \pm 0.091) \mathrm{c}$ & $1.17( \pm 0.014) \mathrm{b}$ & $0.61( \pm 0.003) \mathrm{b}$ \\
& Arrope & 2 & $250 \mu \mathrm{L}$ & $3.22( \pm 0.458) \mathrm{b}$ & $0.825( \pm 0.069) \mathrm{b}$ & $0.66( \pm 0.551) \mathrm{ab}$ \\
CPCI-SC & Flour & 5 & $0.10 \mathrm{~g}$ & $120.36( \pm 15.65) \mathrm{a}$ & $1.79( \pm 0.035) \mathrm{a}$ & $1.28( \pm 0.106) \mathrm{a}$ \\
& Arrope & 7 & $250 \mu \mathrm{L}$ & $19.30( \pm 16.602) \mathrm{ab}$ & $1.63( \pm 0.084) \mathrm{a}$ & $1.08( \pm 0.318) \mathrm{a}$ \\
\hline
\end{tabular}

Different letters indicate significant differences $(p<0.05)$ among methods. Compare letter differences for food type.

DNA extract showing low A260/230 values could mean low quality PCR amplicons. The addition of reagents or components, such as phenol, triple amount of beta-mercaptoethanol, Proteinase K, Sarcosyl and Sorbitol, were factors that influenced the quality of DNA extraction in the CPCI-SC method. In earlier studies, a Sorbitol buffer was able to remove most of the polysaccharides and other contaminants during DNA extraction from Dimorphandra mollis leaf (Souza et al., 2012), while Sarcosyl was able to remove polyphenols during lysis step of honey samples (Jain et al., 2013). Moreover, proteins, lipids, carbohydrates, and cell debris are removed through the addition of a mixture of phenol and chloroform (Chomczynski and Sacchi, 2006). Alternatively, columns with silica membrane help remove the rest of the contaminants (Ohmori et al., 2008).

With regards to the difficulty of handling, the CCI-P and CCI-SC methods turned problematic after Chloroform/Isoamyl alcohol was added, since it was difficult to recover the supernatant. In particular, the lower phases of the solution lose stability quickly. Thus, the contaminant components mix with the DNA precipitated in the next stages of the CCI-P method, resulting in a highly viscous extract. The presence of polysaccharides is inadequate for PCR due to their Taq polymerase inhibitory activity (Saikar et al., 2013; Schrader et al., 2012). This viscosity can be avoided with the CCI-SC method when transferring the liquid to the mini column. However, it remains as contaminated as the one from the CCI-P method. As the CK method is a standardized extraction kit, the time and complexity involved were lower. However, the A260/A280 and A260/A230 ratio parameters were not optimal.
Most of the PCR amplifications with ISSR and RAPD using leaf DNA from different DNA extraction methods were successful, except for the ISSR amplifications from CCI-P extracted DNA. Some samples did not show reproducibility in their resulting PCR patterns, such as the Azapa and Totoral samples. This could be due to a variation in the amount of PCR inhibitors present in samples from each location. Polysaccharides and polyphenols, among others, are cellular products that interfere with the extraction and purification of DNA, affecting its subsequent amplification (Ginwal and Maurya, 2010). According to Jiménez-Aspee et al. (2017), some chañargenotypes from the Atacama Desert present differences in flavonoid productions. Therefore, the difficult extraction of clean DNA from chañar genotypes coming from Azapa and Totoral, might be due to their high flavonoid content. Plants permanently exposed to stress conditions synthesize high quantities of polysaccharides, polyphenols and other secondary metabolites such as alkaloids and flavonoids. Some of these are essential for plant physiological activity and defense (Popovic et al., 2016; Vicente and Boscaiu, 2018). In general, a greater number of amplified bands with the ISSR and RAPD markers were obtained with chañar leaf DNA obtained by the CPCI-SC method. Moreover, this method was tested with Prosopis flexuosa, Prosopis alba, Prosopis tamarugo and Prosopis burkartii leaves, resulting in acceptable DNA quality and yield values (data not shown). Regarding DNA quality, the most important difference between the four methods was the A260/A230 value, with the CPCI-SC method having the most acceptable range, which could have influenced a better quality of the subsequent PCRs. Therefore, DNA extraction 
tests do not only need to evaluate the A260/A280 parameter, but also the A260/A230 parameter, especially when targeting plant tissue of species that inhabit abiotic stress environments, such as the Atacama Desert. The amplification of ISSR and RAPD markers requires high purity DNA extraction in order to show a robust and reproducible genetic profile (Sucher et al., 2012). For example, for Dalbergia sissoo, only the DNA extraction method with the purest DNA showed clear banding patterns from the RAPD and ISSR analysis (Ginwal and Maurya, 2010).

Even though the A260/A280 and A260/A230 values for the arrope (1.63 and 1.08, respectively) and flour (1.79 and 1.28, respectively) DNA extract obtained using the CPCI-SC method were not within the acceptable DNA quality range (> 1.8 ), at least they were closer to the optimal value when compared to the other methods. In foods, it is common to obtain low quality and yield values of DNA extractions due to their high level of processing (degradation), high content of PCR inhibitors and high DNA fragmentation (short fragments) (Di Bernardo et al., 2007; Yayla et al., 2018; Amane and Ananthanarayan, 2019). The commercial Purelink ${ }^{\mathrm{TM}}$ Plant DNA extraction kit (CK method) is not designed to extract DNA from food. However, this product was able to extract good quality DNA from wheat flour, but not from chañar flour. As indicated above, the chañar flour extracts showed acceptable DNA quality and even high yield only when using the CPCISC method. A commercial DNA extraction kit for food, DNeasy mericon Food Kit (Qiagen) was also used to compare it with the four protocols. The results showed that the yield and quality of the DNA from flour and arrope obtained with the kit were equal to the values from the CPCI-SC method (data not shown).

Chemical laboratory tests generally use chromatography (HPLC and TLC), spectrometry (MA) and spectroscopy (NMR and FT-NIR) techniques to detect food substances or raw materials (Amane and Ananthanarayan, 2019). However, metabolites can be altered or influenced by light and storage periods, and this is why DNA-based authentication methods could be a good alternative (Mafra et al., 2008). For DNA extracted from food, ISSR and RAPD molecular markers were not used because they are not suitable for this type of matrix, due to the high level of fragmentation and contamination in the extracted DNA. However, the DNA Barcode and SSR markers have been used successfully for this (Galimberti et al., 2013; Scarano and Rao, 2014; Amane and Ananthanarayan, 2019). In our study, only DNA from arrope and flour obtained using the CPCI-SC method allowed for amplification of
DNA barcodes ( $r b c L$ and matK) and SSR marker, respectively. For the PCR amplification of arrope products, shorter primers ( $<100 \mathrm{bp})$ were used, since there are reports (Scarano and Rao, 2014) indicating that DNA fragmentation is a common problem with food products with long shelf life and processed at high temperatures. Given the fact that arrope was boiled for more than four hours, it was surprising to obtain even some DNA. This also suggests a likely reason for the inability to obtain a PCR product from chañar arrope using primers targeting microsatellite Gsp.F119 since the expected fragment is larger than $155 \mathrm{bp}$, which is over the detection limits for products treated at high temperature (Scarano and Rao, 2014). It must be pointed out that only the arrope DNA extractions with A260/A280 and A260/A230 values over 1.6 and 1.1, respectively, allowed for successful amplification of PCR fragments from genes GdtrnL and GdmatK. There are several DNA extraction methods utilized in the analysis of food products (Scarano and Rao, 2014), but most of them are mainly limited by the presence of PCR inhibitors (Wilson, 1997; Schrader et al., 2012). The food chain has constantly evolved in terms of standards and requirements. The traceability of a product has been reported to improve the reliability of the labeling and to certify its origin (Turci et al., 2010; Paracchini et al., 2019). For example, the European Union has established that in order to obtain a genuine product of adequate nutritional value (Turci et al., 2010; Paracchini et al., 2019), traceability assumes a key role in the market. The expansion of international trade has had implications for the safe development of the food chain (Turci et al., 2010). Therefore, regulations that use genetic traceability techniques are appropriate for application in international markets. Information about a food product is essential to allow for informed choices on the part of the consumer. Therefore, the precise and correct identification of a plant species used for food product manufacturing is a basic requirement to avoid fraudulent purchase (Scarano and Rao, 2014).

\section{CONCLUSION}

In conclusion, the CCI-P method showed the highest yield of DNA extracted from leaves, followed by the CCI-SC, CPCI-SC and CK methods. However, the CPCI-SC method was the one that showed the best DNA quality and purity for the two parameters evaluated (A260/A280 and A260/A230). In fact, thanks to this improved quality, the leaf DNA obtained with this method showed a greater amount of PCR fragments with the RAPD marker and an acceptable amount of 
fragments with the ISSR marker. Therefore, this standardized CPCI-SC method can be used to extract DNA from a large number of individuals from chañar to study populations from different locations in the Atacama Desert. On the other hand, the CCI-P method recorded the highest DNA yield from chañar arrope, followed by the CPCI-SC, CCI-SC and CK methods. However, the CPCI-SC method was the only one that yielded good DNA quality based on the two parameters measured (A260/A280 and A260/ A230). This allowed for PCR amplification of the DNA barcode markers, while DNA yielded by the other methods resulted in no amplification. In the case of chañar flour, the CPCI-SC method showed the highest DNA yield, acceptable DNA quality and, consequently, good amplification of the SSR marker and DNA barcode. Therefore, the CPCI-SC DNA is an efficient extraction method for use with leaf tissue and foodstuffs, as well as for supporting genetic studies of populations and traceability for a possible designation of origin of chañar foods.

\section{ACKNOWLEDGEMENTS}

This research was financed by the Regional Innovation Assignment Fund from the Atacama Government of Chile, Code BIP 30432984-0. In addition, the authors would like to thank the Corporación Nacional Forestal (CONAF) for the chañar sampling .

\section{LITERATURE CITED}

Aleksic, J.M., D. StojanoviĆ, B. BanoviĆ, and R. JanČiĆ. 2012. A simple and efficient DNA isolation method for Salvia officinalis. Biochemical Genetics 50:881-892.

Allen, G.C., M.A Flores-Vergara, S. Krasnyanski, S. Kumar, and W.F. Thompson. 2006. A modified protocol for rapid DNA isolation from plant tissues using cetyltrimethylammonium bromide. Nature Protocol 1(5):2320-2325.

Amane, D., and L. Ananthanarayan. 2019. Detection of adulteration in black grambased food products using DNA barcoding. Food Control 104:193-200.

Charpentier, M. 1998. Valores nutricionales de las plantas alimenticias silvestres del norte argentino. Instituto de Cultura PopularComisión Europea, Reconquista, Argentina.

Chomczynski, P., and N. Sacchi. 2006. The single-step method of RNA isolation by acid guanidinium thiocyanate-phenolchloroform extraction: twenty-something years on. Nature Protocols 1(2):581-585.
Contreras, R., V. Porcile, and F. Aguayo. 2018a. Genetic diversity of Geoffroea decorticans, a native woody leguminous species from Atacama Desert in Chile. Bosque 39(2):321332.

Contreras, R., F. Aguayo, A. Guerra, F. Tapia, and V. Porcile. 2018b. Genetic characterization of centennial olive tres from northern Chile: The case of extra virgin olive oil from Huasco in the process of designation of origin. Chilean Journal of Agricultural and Animal Science 34(2):126-139.

Contreras, R., B. Sepúlveda, F. Aguayo, and V. Porcile. 2018c. Rapid diagnostic PCR method for identification of the genera Sarcocornia and Salicornia. Idesia (Chile) 36(3):95-106.

Costagama, M.S., I.C. Zampini, M.R. Alberto, S. Cuello, S. Torres, J. Pérez, et al. 2016. Polyphenols rich fraction from Geoffroea decorticans fruits flour affects key enzymes involved in metabolic syndrome, oxidative stress and inflammatory process. Food Chemistry 190:392-402.

Demeke, T., and G.R. Jenkins. 2010. Influence of DNA extraction methods, PCR inhibitiors and quantification methods on real-time PCR assay of biotechnology-derived traits. Anal. Bioanal. Chem. 396:1977-1990.

Di Bernardo, G., S. Del Gaudio, U. Galderisi, A. Cascino, and M. Cipollaro. 2007. Comparative evaluation of different DNA extraction procedures from food samples. Biotechnology Progress 23:297-301.

Fahmy, T., and P. Aubry. 2003. XLSTAT, version 7.0. Society Addinsoft, New York. Disponible en https://www.xlstat.com/es/ (Consulta 11 Abril 2019).

Galimberti, A., F. De Mattia, A. Losa, I. Bruni, S. Federici, M. Casiraghi, and M. Labra. 2013. DNA barcoding as a new tool for food traceability. Food Research International 50:55-63.

Ginwal, H.S., and S.S. Maurya. 2010. Evaluation and optimization of DNA extraction method for Dalbergia sissoo leaf. Indian Journal of Biotechnology 9:69-73.

Hurrell, J.A., and E. Ulibarri. 2011. Leguminosas medicinales y alimenticias utilizadas en la conurbación Buenos Aires-La Plata, Argentina. Boletín Latinoamericano y del Caribe de Plantas Medicinales y Aromáticas 10(5):443-455. 
Inglis, P.W., M.d.C.R. Pappas, L.V. Resende, and D. Grattapaglia. 2018. Fast and inexpensive protocols for consistent extraction of high quality DNA and RNA from challenging plant and fungal samples for highthroughput SNP genotyping and sequencing applications. PLOS ONE 13(10): e0206085.

Jain, S., F.T.D. Jesus, G.M. Marchioro, and E.D. Araújo. 2013. Extraction of DNA from honey and its amplification by PCR for botanical identification. Food Science and Technology 33(4):753-756.

Jiménez-Aspee, F., C. Theoduloz, M.D.P.C. Soriano, M. Ugalde-Arbizu, M.R. Alberto, I.C. Zampini, et al. 2017. The native fruit Geoffroea decorticans from arid Northern Chile: Phenolic composition, antioxidant activities and in vitro inhibition of proinflammatory and metabolic syndromeassociated enzymes. Molecules 22(9):1565.

Kopecká, J., D. Matoulková, M. Němec, M. Jelínková, and J. Felsberg. 2014. Comparison of DNA extraction methods in terms of yield, purity, long-term storage, and downstream manipulation with brewer's yeast chromosomal DNA. Journal of the American Society of Brewing Chemists 72(1):1-5.

Liu, P.F., L.V. Avramova, and C. Park. 2009. Revisiting absorbance at $230 \mathrm{~nm}$ as a protein unfolding probe. Analytical Biochemistry 389:165-170.

Lorenz, T.C. 2012. Polymerase chain reaction: basic protocol plus troubleshooting and optimization strategies. Journal of Visualized Experiments 63:3998

Lucena-Aguilar, G., A.M. Sánchez-López, C. Barberán-Aceituno, J.A. Carrillo-Ávila, J.A. López-Guerrero, and R. Aguilar-Quesada. 2016. DNA source selection for downstream applications base on DNA quality indicators analysis. Biopreservation and Biobanking 14(4):264-270.

Maestri, D.M., R.H. Fortunato, J.A. Greppi, and A.L. Lamarque. 2001. Compositional studies of seeds and fruits from two varieties of Geoffroea decorticans. Journal of Food Composition and Analysis 14:585-590.

Mafra, I., I. Ferreira, and M. Oliveira. 2008. Food authentication by PCR-based methods. European Food Research and Technology 227:649-665.

Naciri-Graven, Y., S. Caetano, D. Prado, R.T. Pennington, and R. Spichiger. 2005. Development and characterization of 11 microsatellite markers in a widespread neotropical seasonally dry forest tree species, Geoffroea spinosa Jacq. (Leguminosae). Molecular Ecology Notes 5:542-545.
Ohmori, K., H. Tsuchiya, T. Watanabe, H. Akiyama, T. Maitani, T. Yamada, et al. 2008. DNA extraction method using a silica-base resin type kit for the detection of genetically modified papaya. Shokuhin Eiseigaku Zasshi 49(2):63-69.

Orrabalis, C.J., H. Gorostegui, E. Calandri, and C. Guzmán. 2013. Parámetros funcionales y contenido de glucosa en harinas obtenidas de fruto maduro de "chañar" (Geoffroea decorticans) de la zona semiárida y árida de la provincia de Formosa. Multequina 22(1):1522.

Paracchini, V., M. Petrillo, A. Lievens, D. Kagkli, and A. Angers-Loustau. 2019. Nuclear DNA barcodes for cod identification in mildlytreated and processed food products. Food Additives \& Contaminants: Part A 36(1):1-14.

Pereira, L., S. Gomes, and P. Martins-Lopes. 2016. Nucleic acid sample preparation for food traceability. In Micic M. (eds.) Sample Preparation Techniques for Soil, Plant, and Animal Samples. Springer Protocols Handbooks, Humana Press, New York, NY, USA.

Popovic, B.M., D. Stajner, R. Zdero-Pavlovic, V. Tumbas-Saponjac, J. Canadanovic-Brunet, et al. 2016. Water stress induces changes in polyphenol profile and antioxidant capacity in poplar plants (Populus spp.). Plant Physiology and Biochemistry 105:242-250.

Reynoso, M.A., A. Sánchez-Riera, and N.R. Vera. 2016. Nutraceutical properties and safety evaluation of fruits and arrope of Geoffroea decorticans (Chañar). Journal of Nutrition \& Food Sciences 6(2):485.

Saikar, P., S. Chouhan, N. Batav, and R. Sharma. 2013. Optimization of DNA isolation process and enhancement of RAPD PCR for low quality genomic DNA of Terminalia arjuna. Journal of Genetic Engineering and Biotechnology 11:17-24.

Scarano, D., and R. Rao. 2014. DNA markers for food products authentication. Diversity 6:579-596.

Souza, H.A., L.A. Muller, R.L. Brandão, and M.B. Lovato. 2012. Isolation of high quality and polysaccharide-free DNA from leaves of Dimorphandra mollis (Leguminosae), a tree from the Brazilian Cerrado. Genetics and Molecular Research 11:756-764.

Schrader, C., A. Schielke, L. Ellerbroek, and R. Johne. 2012. PCR inhibitors - occurrence, properties and removal. Journal Applied Microbiology 113:1014-1026. 
Sucher, N.J., J.R. Hennell, and M.C. Carles. 2012. Plant DNA fingerprinting and barcoding: methods and protocols. Humana Press, New York, USA.

Turci, M., M.L.S. Sardaro, G. Visioli, E. Maestri, M. Marmiroli, and N. Marmiroli. 2010. Evaluation of DNA extraction procedures for traceability of various tomato products. Food Control 21(2):143-149.

Vicente, O., and M. Boscaiu. 2018. Flavonoids: Antioxidant compounds for plant defense and for a healthy human diet. Notulae Botanicae Horti Agrobotanici Cluj-Napoca 46(1):14-21.

Williams, J.G., A.R. Kubelik, K.L. Livak, J.A. Rafalski, and S.V. Tingey. 1990. DNA polymorphisms amplified by arbitrary primers are useful as genetic markers. Nucleic Acids Research 18(22):6531-6535.
Wilson, I.G. 1997. Inhibition and facilitation of nucleic acid amplification. Applied and Environment Microbiology 63:3741-3751.

Yayla, M.E., C.E. Doğan, and Ş. Sarioğlan. 2018. Purification and analysis of DNA from low DNA content food samples. Journal of Consumer Protection and Food Safety 14:147-155.

Zietkiewicz, E., A. Rafalski, and D. Labuda. 1994. Genome fingerprinting by simple sequence repeat (SSR-Anchored) polymerase chain reaction amplification. Genomics 20:176-183. 